\title{
ANALISIS POTENSI BPRS TERHADAP PENINGKATAN OMSET USAHA MENENGAH KECIL DAN MIKRO (UMKM) DI KABUPATEN BIREUEN Studi Kasus : PT. BPRS Rahmania Dana Sejahtera
}

\author{
Junardi*1) dan Azhari ${ }^{2)}$ \\ 1, Magister Manajemen Fakultas Ekonomi Bisnis UNIKI \\ 2 Dosen Fakultas Ekonomi dan Bisnis UNIKI \\ *email: jundinardi@gmail.com
}

DOI:

https://doi.org/10.55178/idm.v1i2.201

ABSTRACT

Article history

Received:

September 1 ${ }^{\text {st }}, 2020$

Revised:

September 10, 2020

Accepted:

September 25, 2020

Page:

$29-43$

Keywords:

Third Party Fund,

Asset,

Financing,

Turnover
This study aims to determine how much influence the Third Party Fund, Asset To Micro, Small and Medium Enterprises (UMKM) through UMKM financing in Bireuen Regency by taking PT. BPRS Rahmania Dana Sejahtera as a case study. This type of research uses quantitative approach, namely research based on numbers and statistical analysis. This type of quantitative research is included in descriptive research. Data used in this research is secondary data, by collecting annual published financial reports of PT. BPRS Rahmania Dana Sejahtera from 2010 to 2019 per quarter, which is time series data. Data then classified based on existing criteria determined. These data are obtained from the official website of Otoritas Jasa Keuangan www.ojk.go.id. Because the object of research observation is the amount of turnover UMKM, then the population in this study were PT. BPRS Rahmania Dana Sejahtera's customers which already uses financing services from 2010 to 2019. And due to data limitations, then all population data is sampled. The analysis technique used is path analysis method. The results of this study is total third party fund influence positive and significant on financing of UMKM amounted to 46,46\%. There is a positive and significant influence between assets to UMKM financing amounted $51,27 \%$. There is a positive and significant influence between third party fund and assets to UMKM financing amounted 97,7\%. Then there is a positive and significant influence between UMKM financing on UMKM turnover amounted $98 \%$. And there is a positive and significant influence of third party fund to assets amounted $94 \%$.

\section{Pendahuluan (Introduction)}

Sektor perdagangan termasuk ke dalam lima besar sektor utama pendukung perekonomian di Kabupaten Bireuen. Pada tahun 2017, pedagang kecil masih mendominasi sektor perdagangan dengan persentase sebesar $92 \%$ dari jumlah seluruh pedagang. Sedangkan pedagang menengah dan pedagang besar persentasenya masing-masing hanya $6 \%$ dan $2 \%$ (Kab. Bireuen dalam angka 2018). Pemerintah daerah terus berupaya untuk membangun sejumlah sarana perdagangan untuk mengembangkan sektor perdagangan, terbukti bahwa selama tahun 2015-2017, jumlah sarana perdagangan di Bireuen terus bertambah.

Keberadaan Usaha Menengah Kecil Dan Mikro (UMKM) sangat dibutuhkan masyarakat, khususnya masyarakat dengan kemampuan ekonomi dan keterampilan terbatas. Peranan penting UMKM dalam kehidupan masyarakat adalah sebagai tempat mendapatkan penghasilan, dan mengembangkan potensi atau keterampilan yang mereka miliki (Maryati 2014). UMKM juga memberikan kontribusi sangat penting bagi Perekonomian Indonesia ketika terjadi krisis, dimana UMKM memiliki daya tahan menghadapi krisis ekonomi yang terjadi, karena UMKM tidak banyak memiliki ketergantungan pada faktor eksternal, seperti hutang dalam valuta asing, dan bahan baku impor dalam melakukan kegiatan oprasionalnya (Malik 2008).

UMKM mempunyai peran penting dan strategis dalam pembangunan ekonomi nasional. Selain berperan dalam pertumbuhan ekonomi dan penyerapan tenaga kerja, UMKM juga berperan dalam mendistribusikan hasil-hasil pembangunan. UMKM juga telah terbukti tidak perpengaruh terhadap krisis. Ketika krisis menerpa pada periode tahun 1997-1998, hanya UMKM yang mampu tetap berdiri kokoh. 
Data Badan Pusat Statistik memperlihatkan, pasca krisis ekonomi tahun 1997-1998 jumlah UMKM tidak berkurang, justru meningkat terus, bahkan mampu menyerap 85 juta hingga 107 juta tenaga kerja sampai tahun 2012. Pada tahun itu, jumlah pengusaha di Indonesia sebanyak 56.539.560 unit. Dari jumlah tersebut, UMKM sebanyak 56.534.592 unit atau 99.99\%. Sisanya, sekitar 0,01\% atau 4.968 unit adalah usaha besar. Data tersebut membuktikan, UMKM merupakan pasar yang sangat potensial bagi industri jasa keuangan, terutama bank untuk menyalurkan pembiayaan. Karena sekitar 60 - 70\% pelaku UMKM belum memiliki akses pembiayaan perbankan. (Profil bisnis UMKM, 2015).

Masyarakat dan pelaku usaha berskala ekonomi mikro dan kecil membutuhkan sistem pembiayaan yang lebih mendukung pada kerberhasilan usaha yaitu dengan sistem bagi hasil. Jenis transaksi seperti ini dapat dilakukan oleh perbankan syariah yang merupakan lembaga keuangan dengan prinsip operasional yang didasarkan pada konsep syariah Islam, yang mengharamkan adanya bunga ( $r i b a)$, dan menerapkan sistem bagi hasil (profit loss sharing) pada setiap transaksinya. (Antonio, 2001). Oleh karenanya, maka mucul bank berbasis syariah untuk mendukung kegiatan UMKM di daerah, seperti di Aceh, sangat dibutuhkan dan sangat diterima oleh masyarakat.

Berdasarkan fungsinya BPRS sebagai lembaga keuangan mikro mempunyai tugas mengumpulkan Dana Pihak Ketiga (DPK) dan menyalurkannya kepada nasabah UMKM dan selain usaha mikro, kecil dan menengah dengan melakukan pembiayaan secara syariah, salah satu pembiayaan yang dilakukan adalah akad Murabahah. BPRS yang ada di Provinsi Aceh terus tumbuh dan berkembang, hal ini telah membuka peluang baru bagi masyarakat kecil khsususnya di kawasan pendesaan untuk memperoleh modal usaha. Selain itu kehadiran BPRS juga membantu masyarkat menginginkan modal atau pembiayaan dalam jumlah kecil, karena pembiaayan yang diberikan oleh BPRS adalah pembiayaan yang difokuskan pada pembiayaan mikro, kecil dan menengah.

Peran BPRS (Bank Pembiayaan Rakyat Syariah) dalam memberikan pembiayaan bedasarkan golongan pembiayaan pada sektor ekonomi di Provinsi Aceh, dapat dilihat pada tabel di bawah ini.

Tabel 1. BPRS Provinsi Aceh Bedasarkan Golongan Pembiayaan tahun 2014-2018 (Rp juta)

\begin{tabular}{|l|l|l|l|l|l|l|}
\hline \multicolumn{1}{|c|}{ GOL PEMBIAYAAN } & \multicolumn{1}{|c|}{$\mathbf{2 0 1 4}$} & \multicolumn{1}{|c|}{$\mathbf{2 0 1 5}$} & \multicolumn{1}{|c|}{$\mathbf{2 0 1 6}$} & \multicolumn{1}{|c|}{$\mathbf{2 0 1 7}$} & \multicolumn{1}{c|}{$\mathbf{2 0 1 8}$} & $\mathbf{g}(\boldsymbol{\%})$ \\
\hline Usaha Kecil dan Menengah & 55.835 & 64.637 & 76.333 & 102.901 & 118.456 & 20 \\
\hline Porsi dari total pembiayaan (\%) & 70,21 & 62,94 & 59,08 & 61,23 & 60,64 & \\
\hline Selain Usaha Kecil dan Menengah & 23.688 & 38.053 & 52.862 & 65.160 & 76.894 & 20 \\
\hline Porsi dari total Pembiayaan (\%) & 29,79 & 37,06 & 40,92 & 38,8 & 39,36 & \\
\hline Total Pembiayaan & 79.524 & 102.690 & 129.195 & 168.061 & 195.350 & \\
\hline
\end{tabular}

Dari tabel di atas tanpak bahwa selama periode 2014 - 2018 telah terjadi kenaikan jumlah pembiayaan yang diberikan oleh BPRS terhadap sektor usaha kecil dan menengah, dimana pertumbuhan rata-rata pembiayaan untuk UMKM selama peride tahun 2014 - 2018 adalah 20\% dan untuk pembiayaan selain dari UMKM pertumbuhan sebesar 20\%. Dari porsi pembiayaan UMKM mendapat pembiayaan yang lebih besar dibandingkan selain UMKM. Hal ini menunjukkan bahwa BPRS memiliki peran dalam mendorong usaha UMKM.

Data tersebut menjadi perhatian semua pihak, untuk memberikan porsi lebih besar terhadap bisnis skala mikro, menengah dan kecil pada lembaga keuangan syariah. Pemerintah eksekutif dan legislatif membuktikan perhatiannya terhadap UMKM dengan meluncurkan UU No. 20 Tahun 2008 tentang UMKM. Maka dibuat peraturan yang menjadi payung hukum, gerak UMKM menjadi semakin leluasa. Persoalan klasik seperti akses permodalan kepada lembaga keuangan pun mulai bisa teratasi. Karena di dalam peraturan itu tercantum mengenai perluasan pendanaan dan fasilitasi oleh perbank dan dan lembaga jasa keuangan non-bank.

Namun demikian, nasabah UMKM mengalami permasalahan dengan tidak lancarnya angsuran pembiayaan kepada BPRS yang notabene akad yang digunakan adalah murabahah. Hal ini dapat juga berpengaruh kepada omset dan keuntungan nasabah UMKM yang mengalami penurunan. Penurunan omset dan keuntungan nasabah UMKM ini dapat terjadi karena lemahnya akad wakalah yang digunakan oleh BPRS, artinya pengajuan awal ke BPRS untuk pembiayaan modal kerja tetapi nasabah menggunakannya untuk konsumtif yang pada akhirnya tidak dapat dijadikan untuk mengembangkan usaha.

Oleh karena itu, pada penelitian ini akan dibahas tentang "Analisis Potensi BPRS Terhadap Peningkatan Omset UMKM di Kabupaten Bireuen. (Studi Kasus : PT BPRS Rahmania Dana Sejahtera)" 
Pendirian PT. Bank Pembiayaan Rakyat Syariah (PT. BPRS) Rahmania Dana Sejahtera, dimulai operasionalnya pada tanggal 28 April 2010, dengan pedoman UU No 21 tahun 2008 sesuai dengan konsep perbankan di Indonesia terutama dalam rangka ikut mengembangkan dan memberikan alternative kepada masyarakat untuk menyimpan dananya dengan aman, dan memberikan solusi pembiayaan terutama lembaga keuangan yang mampu menyentuh masyarakat kecil dengan konsep syariah yang Islami.

Sejak mulai beroperasi pada akhir kwartal pertama tahun 2010 ini, PT. BPRS Rahmania Dana Sejahtera berbadan hukum PT yang di sahkan dengan Notaris SITI SAFARIJAH, S.H No. 16 pada tanggal 20 Januari 2009 yang telah di daftarkan di Dekham dengan no AHU-28613 AH 01.01 tahun 2009 pada tanggal 25 Juni 2009 terus berusaha untuk mengembangkan operasional bank yang berbasis syariah dan menunjukkan existensinya ditengah-tengah ketatnya persaingan bisnis perbankan baik yang konvensional ataupun syariah serta menjamurnya lembaga-lembaga penyaluran dana untuk pembiayaan/kredit seperti Baitul Qiradh, Kredit Finance, Lembaga Kredit Mikro, PNM-ULAM di Kota Juang Bireuen.

Secara umum kondisi PT. BPRS Rahmania Dana Sejahtera sejak beroperasi sampai dengan akhir tahun 2010 ini, belum dapat memberikan kontribusi dan keuntungan. Sebagaimana bisnis lainnya maka perkembangan usaha perbankan khususnya PT. BPRS Rahmania Dana Sejahtera dari mulai beroperasi hingga saat ini masih mengalami kerugian.

Penelitian yang dilakukan pada PT. BPRS Rahmania Dana Sejahtera di Kabupaten Bireuen ini, bertujuan untuk mengetahui: 1) pengaruh dana pihak ketiga terhadap pembiayaan UMKM, 2) Untuk mengetahui berapa besar pengaruh Asset terhadap pembiayaan UMKM, 3) pengaruh dana pihak ketiga, asset terhadap pembiayaan UMKM, 4) pengaruh pembiayaan UMKM terhadap peningkatan omset UMKM, dan 5) pengaruh dana pihak ketiga terhadap peningkatan asset.

\section{Tinjauan Literatur (Literature Review)}

\section{a. Timbul Profesi Perdagangan (Muamalah) terkait dengan hadist Nabi Muhammad SAW.}

Berkaitan dengan usaha perdagangan, masyarakat Aceh memulai usaha dengan mengingat hadist yang menjelaskan tentang muamalah yang menjadi pemicu usaha ekonomi rakyat dan mengangkat ekonomi di daerah aceh, karena dengan adanya alasan syar' $i$ maka banya masyarakat yang memilih profesi berdagang dari pada profesi lain. Ini juga salah satu alasan masyarakat di Kabupaten Bireuen lebih banyak pedagang dari pada profesi lain. Terbukti dengan hadist Rasulullah yang menjalaskan manfaat bagi orang-orang yang memilih profesi berdagang untuk meningkatkan ekonomi keluarganya. Seperti hadist "Biarlah manusia saling memberi rezeki kepada yang lainnya" (HR. Al Baihaqi). Atau hadist yang diriwayatkan oleh Athabrani; "Apabila Allah menginginkan kemajuan dan kesejahteraan kepada suatu kaum, maka Allah akan memberi mereka karunia kemudahan dalam jual-beli dan kehormatan diri. Namun bila Allah menginginkan bagi suatu kaum kemacetan dan kegagalan maka Allah bagi mereka pintu penghianatan. (HR. Athabrani)

Pedagang yang jujur amanatnya kelak di hari kiamat bersama-sama para nabi, shidiqin dan para shuhada. (HR. Attirmidzi dan Ibnu Majah). Nabi Muhammad SAW. melarang menjual beli uang muka (persekot). Artinya memperjual belikan uang muka. (HR. Abu Dawud). Apabila terjadi perselisihan antara penjual dan pembeli maka keputusan ada di tangan penjual. Apakah pembeli menyetujuinya atau jual beli batal. (HR. Abu Hanifah).

Allah memberkahi penjualan yang mudah, pembelian yang mudah, pembayaran yang mudah dan penagihan yang mudah. (HR. Aththahawi).

Rasulullah SAW, melarang penjualan karena terpaksa (dipaksa menjual karena terdesak kebutuhan) dan melarang penjualan dengan pemalsuan (penipuan). (HR. Mashabih Assunnah). Tidak sah perceraian, penjualan atau pembelian yang dilakukan orang gila. (HR. Abu Hanifah). Orang yang mendatangkan barang dagangan (impor) untuk dijual selalu akan memperoleh rezeki dan orang yang menimbun barang akan dikutuk Allah. (HR. Ibnu Majah dan Aththusi). Barangsiapa menimbun bahan pangan kebutuhan kaum muslimin maka Allah akan menimpanya dengan kebangkrutan dan penyakit lepra (HR. Ahmad dan Ibnu Majah)

Rasulullah SAW, memutuskan untuk mendahulukan penyelesaian hutang sebelum melaksanakan wasiat. (HR. Al Hakim). Berhati-hatilah dalam berhutang. Sesungguhnya berhutang itu suatu kesedihan pada malam hari dan kerendahan diri (kehinaan) di siang hari. (HR. Al Baihaqi). Orang kaya yang menundanunda (mengulur-ulur waktu) pembayaran hutangnya adalah kezaliman (HR. Al Bukhari). Roh seorang muslim masih terkatung-katung (sesudah wafatnya) sampai hutangnya di dunia dilunasi. (HR. Ahmad). 
Jangan menimbulkankan ketakutan pada dirimu sendiri sesudah terasa olehmu keamanan (ketentraman). Para sahabat bertanya, "Apa yang menimbulkan ketakutan itu, ya Rasulullah?" Beliau menjawab, "Hutang". (HR. Ahmad).

Seorang hamba muslim yang membayar hutang saudaranya maka Allah akan melepaskan ikatan penggadaiannya pada hari kiamat. (HR. Mashabih Assunnah). Hutang adalah bendera Allah di muka bumi. Apabila Allah hendak menghinakan seorang hamba maka diikatkan ke lehernya. (HR. Ahmad dan Al Hakim). Waspadalah dan hindarilah do'a orang yang dalam kesulitan untuk membayar kembali hutangnya. (HR. Adailami). Apabila orang yang punya hak mengetahui kebaikan yang akan diperolehnya disebabkan menunda tuntutannya atas haknya pasti orang yang punya tuntutan atas haknya akan lari menjauhi orang yang dituntutnya. (HR. Al Bukhari).

Apabila seseorang menghutangi orang lain maka janganlah mengambil suatu kelebihan (komisi). (HR. Ahmad). Unta yang digadaikan boleh ditunggangi karena dikeluarkan biaya pemeliharaannya dan susunya boleh diminum oleh orang yang menyimpan unta tersebut. (HR. Al Bukhari). Pembunuh tidak bisa menerima warisan dari yang dibunuhnya. (HR. Attirmidzi).

\section{b. Peran Bank Syariah dalam Perekonomian}

Bank merupakan lembaga keuangan yang terpenting yang mempengaruhi perekonomian baik secara mikro maupun secara makro. Fungsinya sebagai perantara keuangan (financial intermediary) antara pihak yang surplus dengan pihak yang membutuhkan dana atau defisit. Dalam menjalankan usahanya sebagai lembaga keuangan yang menjual kepercayaan dan jasa, setiap bank berusaha sebanyak mungkin menarik nasabah baru, memperbesar dananya dan juga memperbesar pemberian kredit dan jasa-jasanya (Simorangkir, 2004).

Berhubungan dengan perbankan maka tidak lepas dari halal dan haram, riba dan non riba yang dihasilkan oleh transaksi yang terjadi di perbankan syariah. Dalam hal ini Al-Qur'an sebagai pedoman bagi manusia dalam segala kehidupan khususnya perdagangan maka dikenal dengan syariah dan non syariah (konvensional). Ada banyak ayat Al-Qur'an yang menjelaskan tentang keharaman riba seperti Surat $\mathrm{Al}$ Baqarah, ayat 275: Orang-orang yang makan (mengambil) riba' tidak dapat berdiri melainkan seperti berdirinya orang yang kemasukan syaitan lantaran (tekanan) penyakit gila. Keadaan mereka yang demikian itu, adalah disebabkan mereka berkata (berpendapat), sesungguhnya jual beli itu sama dengan riba, padahal Allah telah menghalalkan jual beli dan mengharamkan riba'. Orang-orang yang telah sampai kepadanya larangan dari Tuhannya, lalu terus berhenti (dari mengambil riba), maka baginya apa yang telah diambilnya dahulu (sebelum datang larangan); dan urusannya (terserah) kepada Allah. Orang yang kembali (mengambil riba), maka orang itu adalah penghuni-penghuni neraka, mereka kekal di dalamnya.

Surat An-Nisa, ayat 161; Dan karena mereka menjalankan riba, padahal sesungguhnya mereka telah dilarang darinya dan karena mereka memakan harta orang dengan cara yang tidak sah (bathil). Kami telah menyediakan untuk orang-orang kafir diantara mereka azab yang pedih. Surat Ali 'Imran, ayat 130; Hai orang-orang yang beriman, janganlah kamu memakan riba dengan berlipat ganda dan bertakwalah kamu kepada Allah supaya kamu mendapat keberuntungan. Surat Ar-Rum, ayat 39; Dan sesuatu riba (tambahan) yang kamu berikan agar dia bertambah pada harta manusia, maka riba itu tidak menambah pada sisi Allah.

Menurut Undang-undang No 21 tahun 2008 tentang Perbankan Syariah mendefinisikan banwa Bank Syariah sebagai bank yang menjalankan kegiatan usaha berdasarkan prinsip syariah dan menurut jenisnya terdiri dari Bank Umum Syariah, dan Bank Pembiayaan Rakyat Syariah (BPRS). Secara umum, bank syariah merupakan lembaga yang melaksanakan tiga fungsi utama, yaitu menerima/menghimpun dana, menyalurkan dana, dan memberikan berbagai jasa-jasa perbankan syariah, seperti mengirimkan uang dan menawarkan produk yang memudahkan nasabah dalam bermuamalah.

Dalam aspek kehidupan bisnis dan transaksi di dunia Islam yang mempunyai sistem perekonomian berbasis dari nilai-nilai dan prinsip-prinsip syariah yang bersumber dari Al-Quran dan Al-Hadits. Sistem perekonomian Islam saat ini, sudah berlaku UU No. 3 Tahun 2006 tentang Perubahan UU No. 7 Tahun 1989 tentang Peradilan Agama maka lebih dikenal dengan istilah Sistem Ekonomi Syariah (Ali; 2008).

\section{c. BPRS}

Bank Pembiayaan Rakyat Syariah (BPRS) adalah bank yang melaksanakan kegiatan usaha berdasarkan prinsip syariah yang dalam kegiatannya tidak memberikan jasa dalam lalu lintas pembayaran. BPRS merupakan badan usaha yang setara dengan bank perkreditan rakyat konvensional dengan bentuk hukum perseroan terbatas, perusahaan daerah, atau koperasi. BPRS sebagai salah satu lembaga di perbankan memiliki fungsi intermediasi keuangan (Jianti, 2015). 
Menurut Iqbal dan Mirakhor (2008), fungsi intermediasi keuangan merupakan proses pengumpulan/ pembelian surplusdana dari sektor usaha, pemerintah maupun rumah tangga, untuk disalurkan kepada unit ekonomi yang defisit. Dalam kegiatan keuangannya, BPRS memfasilitasi fungsi intermediasi ini adalah dengan tersedianya akad atau kontrak yang diterapkan sesuai dengan ketentuan syariah. Serangkaian kontrak tersebut dirangkum dalam kontrak intermediasi. Kontrak intermediasi ini terdiri dari tiga prinsip yang mencakup beberapa akad didalamnya, yaitu prinsip partnership, trust, dan security.

Dalam sistem perbankan di Indonesia terdapat dua macam sistem operasional perbankan, yaitu bank konvensional dan bank syariah. Sesuai UU No. 21 tahun 2008 tentang Perbankan Syariah, Bank Syariah adalah bank yang menjalankan kegiatan usaha berdasarkan prinsip syariah, atau prinsip hukum Islam yang diatur dalam fatwa Majelis Ulama Indonesia seperti prinsip keadilan dan keseimbangan ('adl wa tawazun), kemaslahatan (maslahah), universalisme (alamiyah), serta tidak mengandung gharar, maysir, riba, zalim dan obyek yang haram. Selain itu, Undang-Undang Perbankan Syariah juga mengamanahkan bank syariah untuk menjalankan fungsi sosial dengan menjalankan fungsi seperti lembaga baitul mal, yaitu menerima dana yang berasal dari zakat, infak, sedekah, hibah, atau dana sosial lainnya dan menyalurkannya kepada pengelola wakaf (nazhir) sesuai kehendak pemberi wakaf (wakif).

Pelaksanaan fungsi pengaturan dan pengawasan perbankan syariah dari aspek pelaksanaan prinsip kehatihatian dan tata kelola yang baik dilaksanakan oleh OJK sebagaimana halnya pada perbankan konvensional, namun dengan pengaturan dan sistem pengawasan yang disesuiakan dengan kekhasan sistem operasional perbankan syariah. Masalah pemenuhan prinsip syariah memang hal yang unik bank syariah, karena hakikinya bank syariah adalah bank yang menawarkan produk yang sesuai dengan prinsip syariah. Kepatuhan pada prinsip syariah menjadi sangat fundamental karena hal inilah yang menjadi alasan dasar eksistensi bank syariah. Selain itu, kepatuhan pada prinsip syariah dipandang sebagai sisi kekuatan bank syariah. Dengan konsisten pada norma dasar dan prinsip syariah maka kemaslahatan berupa kestabilan sistem, keadilan dalam berkontrak dan terwujudnya tata kelola yang baik dapat berwujud.

Berdasarkan Undang-Undang Republik Indonesia Nomor 21 Tahun 2008 tentang Perbankan Syariah dalam pasal 1 disebutkan bahwa BPRS adalah Bank Syariah yang dalam kegiatannya tidak memberikan jasa dalam lalu lintas pembayaran. Dalam Peraturan Bank Indonesia tahun 2009 tentang BPRS menjelaskan bahwa badan hukum BPRS adalah Perseroan Terbatas (PT). BPRS hanya boleh dimiliki oleh Warga Negara Indonesia (WNI) dan/atau badan hukum Indonesia, pemerintah daerah atau kemitraan antara WNI atau badan hukum Indonesia dengan pemerintah daerah. BPRS sangat berperan dalam memberdayakan ekonomi umat dengan mengembangkan ekonomi golongan lemah yaitu dengan mengembangkan UMKM.

Bank Syariah di Indonesia saat ini terdiri dari 3 (tiga) macam yaitu Bank Umum Syariah (BUS), Unit Usaha Syariah (UUS) dan Bank Pembiayaan Rakyat Syariah (BPRS). Dimana ruang lingkup kegiatan usaha masing-masing bank tersebut berbeda, sesuai dengan Standar Oprasional Prosedur (SOP) yang dimiliki

Pada umumnya BUS, UUS, dan BPRS merupakan bank alternatif yang diperuntukkan bagi masyarakat yang menjalankan usaha mikro kecil menengah dan yang menginginkan perbankan yang benar-benar syariah (menjalankan prinsip-prinsip syariah). Kehadiran Bank Pembiayaan Rakyat Syariah (BPRS) di Indonesia semakin menambah daftar nama perbankan syariah, karena BPRS dalam sistem perbankan di Indonesia merupakan sebuah lembaga keuangan dalam memenuhi kebutuhan masyarakat atas transaksi pembiayaan yang tidak berbasis riba.

Kegiatan usaha Bank Pembiayaan Rakyat Syariah (BPRS) meliputi :

(a) Menghimpun dana dari masyarakat dalam bentuk: (1) Simpanan berupa tabungan atau yang dipersamakan dengan itu berdasarkan akad wadiah atau akad lain yang tidak bertentangan dengan prinsip syariah, (2) Investasi berupa deposito atau tabungan atau bentuk lain yang dipersamakan dengan itu berdasarkan akad mudharabah atau akad lain yang tidak bertentangan dengan Syariah;

(b) Menyalurkan dana kepada masyarakat dalam bentuk: (1) Pembiayaan bagi hasil berdasarkan akad mudharabah atau musyarakah, (2) Pembiayaan berdasarkan akad murabahah, salam atau isti'na, (3).Pembiayaan berdasarkan akad qardh, (4) Pembiayaan penyewaan barang bergerak atau tidak bergerak kepada nasabah berdasarkan akad ijarah, dan sewabeli dalam bentuk akad ijarah muntahiyah bittamlik, dan (5) Pengambil alihan utang berdasarkan akad wakalah;

(c) Menempatkan dana pada Bank Syariah lain dalam bentuk titipan bedasarkan akad wadiah atau investasi berdasarkan akad mudharabah dan/atau akad lain yang tidak bertentangan dengan prinsip Syariah;

(d) Memindahkan uang, baik untuk kepentingan sendiri maupun untuk kepentingan nasabah melalui rekening BPRS yang ada di Bank Umum Syariah, Bank Umum Konvensional, dan UUS; 
(e) Menyediakan produk atau melakukan kegiatan usaha Bank Syariah lainnya yang sesuai dengan prinsip Syariah berdasarkan persetujuan Bank Indonesia atau OJK RI.

Sesuai dengan fungsi bank sebagai financial intermediary, BPRS menjalankan aktivitasnya dengan menghimpun dana pihak ketiga dari masyarakat berupa tabungan dan deposito serta menyalurkan kembali dana tersebut kepada masyarakat dalam bentuk pembiayaan. Sebagai BPRS yang mengembangkan usahausaha produktif investasi dalam meningkatkan kualitas kegiatan UMKM dengan mendorong kegiatan menabung dan menunjang pembiayaan ekonomi. Pertumbuhan bisnis BPRS selalu menunjukkan kinerja positif, dapat dilihat dari tabel total Asset, pembiayaan, dan total dana pihak ketiga yang selalu meningkat setiap tahunnya. Sebagai gambaran, sejak tahun 2014 sampai 2018, Kondisi BPRS di Provinsi Aceh adalah:

Tabel 2. Total Aset, Pembiayaan, Dana Pihak Ketiga, BPRS Provinsi Aceh Tahun 2014 - 2018 (Rp Juta)

\begin{tabular}{|l|c|c|c|}
\hline \multicolumn{1}{|c|}{ TAHUN } & ASSET & PEMBIAYAAN & $\begin{array}{c}\text { DANA PIHAK } \\
\text { KETIGA }\end{array}$ \\
\hline 2014 & 123.131 & 79.524 & 77.095 \\
\hline Kenaikan setiap Tahun (\%) & 17,74 & 21,68 & 21,82 \\
\hline 2015 & 166.731 & 102.690 & 104.871 \\
\hline Kenaikan setiap Tahun (\%) & 26,15 & 22,56 & 26,49 \\
\hline 2016 & 183.513 & 129.195 & 112.867 \\
\hline Kenaikan setiap Tahun (\%) & 9,14 & 20,52 & 171.853 \\
\hline 2017 & 260.677 & 168.061 & 34,32 \\
\hline Kenaikan setiap Tahun (\%) & 29,60 & 23,13 & 210.641 \\
\hline 2018 & 298.625 & 195.350 & 18,41 \\
\hline Kenaikan setiap Tahun (\%) & 12,71 & 13,97 & \\
\hline
\end{tabular}

Sumber : Statistik Perbankan Syariah Tahun 2014-2018

Dari tabel 2. di atas dapat disimpulkan bahwa pertumbuhan Asset, Pembiayaan, dan Dana Pihak Ketiga (DPK) BPRS di Provinsi Aceh setiap tahun mengalami kenaikan yang cukup signifikan.

\section{d. Usaha Menengah Kecil dan Mikro (UMKM)}

Menurut UUD 1945, yang dikuatkan melalui TAP MPR NO.XVI/MPR-RI/1998 tentang Politik Ekonomi dalam rangka Demokrasi Ekonomi, Usaha Mikro, Kecil, dan Menengah perlu diberdayakan sebagai bagian integral ekonomi rakyat yang mempunyai kedudukan, peran, dan potensi strategis untuk mewujudkan struktur perekonomian nasional yang makin seimbang, berkembang, dan berkeadilan.

Selanjutnya dibuatklah pengertian UMKM melalui UU No.9 Tahun 1999 dan karena keadaan perkembangan yang semakin dinamis dirubah ke Undang-Undang No.20 Pasal 1 Tahun 2008 tentang Usaha Mikro, Kecil dan Menengah maka pengertian UMKM adalah sebagai berikut:

1) Usaha Mikro adalah usaha produktif milik orang perorangan dan/atau badan usaha perorangan yang memenuhi kriteria Usaha Mikro sebagaimana diatur dalam Undang-Undang ini.

2) Usaha Kecil adalah usaha ekonomi produktif yang berdiri sendiri, yang dilakukan oleh orang perorangan atau badan usaha yang bukan merupakan anak perusahaan atau bukan cabang perusahaan yang dimiliki, dikuasai, atau menjadi bagian baik langsung maupun tidak langsung dari Usaha Menengah atau Usaha Besar yang memenuhi kriteria Usaha Kecil sebagaimana dimaksud dalam Undang-Undang ini.

3) Usaha Menengah adalah usaha ekonomi produktif yang berdiri sendiri, yang dilakukan oleh orang perorangan atau badan usaha yang bukan merupakan anak perusahaan atau cabang perusahaan yang dimiliki, dikuasai, atau menjadi bagian baik langsung maupun tidak langsung dengan Usaha Kecilatau Usaha Besar dengan jumlah kekayaan bersih atau hasil penjualan tahunan sebagaimana diatur dalam Undang- Undang ini.

4) Usaha Besar adalah usaha ekonomi produktif yang dilakukan oleh badan usaha dengan jumlah kekayaan bersih atau hasil penjualan tahunan lebih besar dari Usaha Menengah, yang meliputi usahanasional milik negara atau swasta, usaha patungan, dan usaha asing yang melakukan kegiatan ekonomi di Indonesia.

5) Dunia Usaha adalah Usaha Mikro, Usaha Kecil, Usaha Menengah, dan Usaha Besar yang melakukan kegiatan ekonomi di Indonesia dan berdomisili di Indonesia.

Diterangkan dalam Undang-Undang Nomor 21 Tahun 2008 Tentang Perbankan Syariah mengenai Pembiayaan. Pembiayaan adalah penyediaan dana atau tagihan yang dipersamakan dengan itu berupa:

1) Transaksi bagi hasil dalam bentuk Mudharabah dan Musyarakah;

2) Transaksi sewa-menyewa dalam bentuk ijarah atau sewa beli dalam bentuk ijarah muntahiya bitamlik; 
3) Transaksi jual beli dalam bentuk piutang murabaha, salam, dan istishna;

4) Pinjam meminjam dalam bentuk piutang qardh, dan

5) Transaksi sewa-menyewa jasa dalam bentuk ijarah dalam transsaksi multijasa".

Sedangkan menurut Kasmir (2008), Pembiayaan adalah penyedia uang atau tagihan yang dipersamakan dengan itu atas persetujuan antar Bank dengan pihak lain yang mewajibkan pihak yang dibiayai untuk mengembalikan uang atau tagihan tersebut setelah jangka waktu tertentu dengan imbalan atau bagi hasil.

Salah satu tujuan BPRS melakukan kegiatan Pembiayaan terhadap para pelaku UMKM adalah untuk memperoleh keuntungan dari bagi hasil usaha para pelaku UMKM. Menurut Kasmir (2008), pemberian Pembiayaan memiliki tujuan utama. Salah satu tujuan utama pemberian Pembiayaan adalah untuk mencari keuntungan. Keuntungan yang dalam hal ini berupa bagi hasil sangat penting bagi kelangsungan hidup Bank, terlebih lagi pada umumnya sebagian besar dana Bank dialokasikan pada pembiayaan sehingga menyumbangkan pendapatan besar.

\section{Metodologi Penelitian (Methodology)}

\section{a. Metode Penelitian dan Unit Analisis}

Jenis penelitian ini menggunakan pendekatan kuantitatif yaitu penelitian berdasarkan angka, dan analisis statistik.Jenis penelitian kuantitatif ini termasuk dalam penelitian deskriptif. Menurut Sugiono (2003 : 11) Penelitian deskriptif yaitu penelitian menggunakan variabel mandiri atau lebih tanpa membuat perbandingan atau menghubungkan variabel lain (Graceris, 2014).

Data yang digunakan dalam penelitian ini adalah data sekunder. Dalam penelitian ini pengumpulan data dilakukan dengan cara mengumpulkan laporan keuangan publikasi tahunan PT. BPRS Rahmania Dana Sejahtera, yaitu laporan keuangan dari tahun 2010 sampai tahun 2019 per triwulan, yang merupakan data time series. Data tersebut kemudian diklasifikasikan berdasarkan kriteria-kriteria yang telah ditentukan. Data-data ini diperoleh dari situs resmi Otoritas Jasa Keungan yaitu www.ojk.go.id.

Karena Objek pengamatan penelitian adalah jumlah Omset dalam kegiatan pembiayaan UMKM yang dilakukan BPRS Rahmania Dana Sejahtera. Maka populasi dalam penelitian ini adalah omset kegiatan usaha BPRS Rahmania Dana Sejahtera yang sudah menggunakan jasa pembiayaan mulai tahun 2010 sampai tahun 2019. Sehubungan dengan keterbatasan data, maka semua data populasi dijadikan sampel, yakni berkaitan dengan Omset kegiatan pembiayaan UMKM selama tahun berdirinya BPRS Rahmania Dana Sejahtera sampai tahun 2019 lalu.

Tabel 3. Data Pembiayaan UMKM, tahun 2010-2019

\begin{tabular}{|c|c|}
\hline Tahun & Jumlah Nasabah \\
\hline 2010 & 100 \\
\hline 2015 & 336 \\
\hline 2016 & 354 \\
\hline 2017 & 500 \\
\hline 2018 & 643 \\
\hline 2019 & 700 \\
\hline TOTAL & $\mathbf{3 . 5 1 8}$ \\
\hline Sumber $:$ PT. BPRS Rahmania Dana Sejahtera, Bireuen 2020
\end{tabular}

\section{b. Operasional Variabel Penelitian}

Tabel 4. Operasional Variabel Penelitian

\begin{tabular}{|l|l|l|}
\hline \multicolumn{1}{|c|}{ Variabel } & \multicolumn{1}{|c|}{ Dimensi } & \multicolumn{1}{c|}{ Indikator } \\
\hline $\begin{array}{l}\text { Dana Pihak } \\
\text { Ketiga }\end{array}$ & $\begin{array}{l}\text { Seluruh Dana Pihak Ketiga yang berasal } \\
\text { dari nasabah }\end{array}$ & $\begin{array}{l}\text { Seluruh penghimpunan dana yang dilakukan dengan } \\
\text { prinsip wadiah dan mudharabah }\end{array}$ \\
\hline Asset & $\begin{array}{l}\text { Asset meliputi Kas, Penempatan, Pembia- } \\
\text { yaan, Pernyertaan, Penyisihan Penghapu- } \\
\text { san Aktiva Produktif, Aktiva Tetap dan } \\
\text { Inventaris }\end{array}$ & $\begin{array}{l}\text { Diukur dengan menjumlahkan seluruh aktiva seperti } \\
\text { kas, Penempatan Dana, PPAP, Aktiva lainnya (tetap, } \\
\text { investasi dan rupa-rupa). }\end{array}$ \\
\hline Pembiayaan & Total jumlah pembiayaan UMKM & $\begin{array}{l}\text { Diukur dengan menjumlahkah seluruh pembiayaan } \\
\text { yang disalurkan dengan prinsip murabahah, } \\
\text { mudarabah, musyarakah. }\end{array}$ \\
\hline $\begin{array}{l}\text { Omset } \\
\text { UMKM }\end{array}$ & $\begin{array}{l}\text { Penjualan UMKM selama satu periode } \\
\text { atau tahun }\end{array}$ & $\begin{array}{l}\text { Total nilai penjualan atau penerimaan dari barang dan } \\
\text { jasa pada suatu periode atau tahun buku yang } \\
\text { bersangkutan }\end{array}$ \\
\hline
\end{tabular}




\section{c. Metode Analisis}

Analisis data dilakukan dengan menggunakan metode analisis jalur yang bertujuan untuk mengetahui potensi BPRS terhadap peningkatan omset UMKM di Kabupaten Bireuen. Data yang diperoleh akan dianalisis secara statistik menggunakan program SPSS (Statistical Programme for Social Science). Metode analisis dengan model persamaan:

$$
\begin{array}{lll}
\mathrm{Y}=\alpha+\beta_{1} \mathrm{X}_{1}+\beta_{2} \mathrm{X}_{2}+\mathrm{e} & \text { Keterangan: } \\
\mathrm{Z}=\alpha+\beta_{2} \mathrm{Y}+\mathrm{e} & \mathrm{X}_{1}=\text { Dana Pihak Ketiga } \\
& \mathrm{X}_{2}=\text { Asset } \\
\mathrm{Y}=\text { Pembiayaan UMKM } & \alpha & =\text { konstanta } \\
\mathrm{Z}=\text { Omset UMKM } & \mathrm{e} & =\text { Standar error } \\
& & \beta_{1}, \beta_{2},=\text { Koefisien regresi }
\end{array}
$$

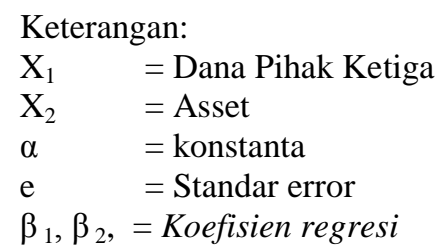

Untuk menerapkan model analisis regresi berganda diatas, maka perlu diawal dilakukan uji asumsi klasik sebagai persyaratannya. Uji asumsi klasik ini dilakukan untuk mengetahui apakah model estimasi yang dipergunakan memenuhi asumsi regresi linier klasik. Hal ini penting dilakukan agar diperoleh parameter yang valid dan andal. Uji asumsi klasik ini terdiri dari uji normalitas, uji multikolinearitas, dan uji heterokedastisitas.

\section{Hasil dan Pembahasan (Results and Discussion)}

\section{a. Analisis Deskripsi}

\section{1). Omset UMKM}

Omset yang dimaksud adalah penjualan yang dicapai UMKM yang juga dapat dipengaruhi besar kecilnya volume usaha. Yang di hitung adalah Total nilai penjualan atau penerimaan dari barang dan jasa pada suatu periode atau tahun buku yang bersangkutan. Berdasarkan pengamatan selama 10 tahun perkembangan PT. BPRS Rahmania Dana Sejahtera ini, menunjukkan hal yang positif dari tahun ke tahun. Walaupun kenaikannya bersifat fluktuatif atau tidak linier (Gambar 1). Hal yang sangat menonjol tampak pada tahun 2017 yang kenaikannya sangat baik dari lima tahun sebelumnya. Rata-rata tingkat pertumbuhan Omset UMKM pada PT. BPRS Rahmania Dana Sejahtera, selama 10 tahun terakhir adalah 25,09\% per tahun. Perkembangan Omset UMKM seiring juga dengan perkembangan Nasabahnya.

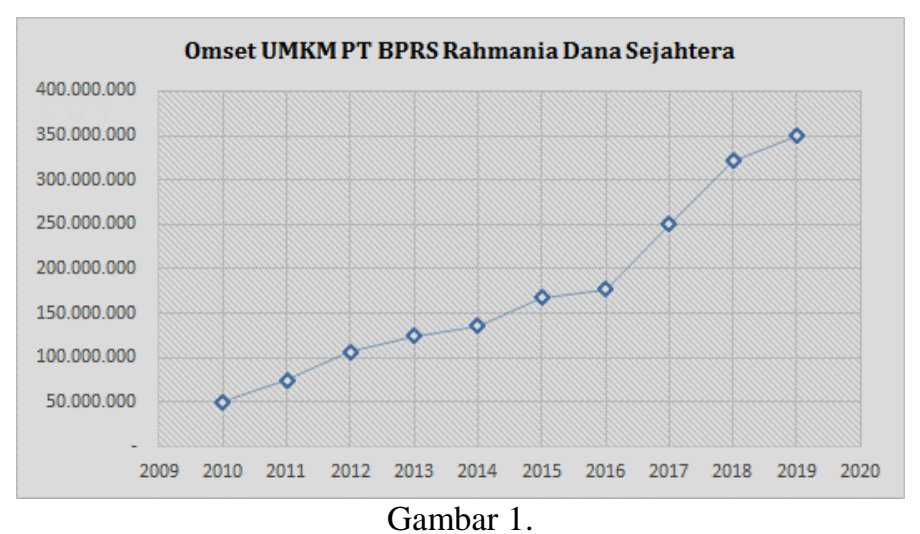

Omset UMKM pada PT. BPRS Rahmania Dana Sejahtera, selama Tahun 2010 - 2019

\section{2). Pembiayaan UMKM}

Pembiayaan yang dimaksudkan di sini adalah total pembiayaan UMKM yang disalurkan oleh BPRS dengan prinsip murabahah, mudharabah dan musyarakah pada setiap akhir tahun. Jadi Pembiayaan UMKM diukur dengan menjumlahkah seluruh pembiayaan yang disalurkan dengan prinsip murabahah, mudarabah, musyarakah.

Pembiayaan $=$ Pembiayaan Murabahah + Mudharabah + Musyarakah

Selama tahun 2010 hingga tahun 2019, pembiayaan UMKM pada PT. BPRS Rahmania Dana Sejahtera, mengalami kenaikan yang sangat berarti. Dengan rata-rata pertumbuhan tahunannya sebesar 45,79\%. Hal yang sangat ekstrim terjadi pada tahun ketiga berdirinya PT. BPRS Rahmania Dana Sejahtera yakni tahun 2012, bisa meningkatkan 148,47\% dari tahun sebelumnya. 
Tabel 5. Perkembangan Pembiayaan UMKM, tahun 2010-2019

\begin{tabular}{|c|c|c|}
\hline TAHUN & PEMBIAYAAN UMKM & Perkembangan (\%) \\
\hline 2010 & 816.647 & 27,80 \\
\hline 2011 & 1.043 .699 & 148,47 \\
\hline 2012 & 2.593 .268 & 31,02 \\
\hline 2013 & 3.397 .632 & 13,52 \\
\hline 2014 & 3.856 .948 & 43,74 \\
\hline 2015 & 5.544 .069 & 26,13 \\
\hline 2016 & 6.992 .620 & 30,53 \\
\hline 2017 & 9.127 .651 & 43,68 \\
\hline 2018 & 13.114 .424 & 47,25 \\
\hline 2019 & 19.310 .555 & Rata-rata $\mathbf{4 5 , 7 9}$ \\
\hline TOTAL & $\mathbf{6 5 . 7 9 7 . 5 1 3}$ & \\
\hline
\end{tabular}

Sumber : PT BPRS Rahmania Dana Sejahtera, Bireuen 2020

\section{3). Dana Pihak Ketiga (DPK)}

Dana pihak ketiga yang dimaksudkan di sini meliputi keseluruhan dana baik deposito maupun tabungan dengan menggunakan akad wadiah dan mudharabah yang masuk ke BPRS yang berasal dari para nasabah, selain modal maupun pinjaman.

Dana Pihak Ketiga $=$ Penghimpunan Dana Prinsip Wadiah + Mudharabah

Berdasarkan pengamatan data dana pihak ketiga yang masuk ke PT. BPRS Rahmania Dana Sejahtera, selam 10 tahun terakhir, tampak bahwa kenaikan sangat baik dan signifikans. Dari awalnya tahun 2010 sejumlah Rp. 174.749.000, meningkatkan tajam pada tahun 2019 menjadi Rp. 15.877.550.000. Dengan rata-rata kenaikan 91,86\% per tahun. Namun mengambil tahun yang normal, yakni dari tahun 2011 sampai 2019, kenaikannya per tahun sebesar 46,67\%. Perkembangan Dana Pihak Ketiga (DPK) pada PT. BPRS Rahmania Dana Sejahtera, dapat digambarkan berikut ini:

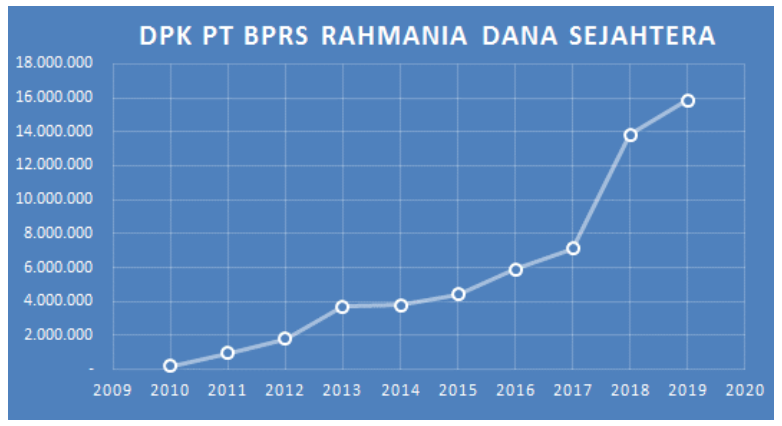

Gambar 2. Jumlah DPK pada PT. BPRS Rahmania Dana Sejahtera, selama Tahun 2010 - 2019

\section{4). Asset}

Asset perbankan syariah meliputi kas, penempatan dana pada BI, penempatan pada bank lain, pembiayaan yang diberikan, penyertaan, Penyisihan Penghapusan Akitva Produktif (PPAP), Aktiva Tetap serta Ruparupa Akitva. Sehingga perhitungan dinyatakan dengan:

Asset $=$ Kas + Penempatan Dana + Pembiayaan + PPAP + Aktiva tetap + Rupa-Rupa Aktiva.

Perkembangan jumlah asset di PT. BPRS Rahmania Dana Sejahtera, selama 10 tahun terakhir sebagaimana ditunjukkan pada tabel 6. yang dapat dinyatakan baik perjalanannya dari tahun ke tahun.

Tabel 6. Asset PT. BPRS Rahmania Dana Sejahtera, tahun 2010-2019

\begin{tabular}{|c|c|c|}
\hline TAHUN & Asset & Perkembangan (\%) \\
\hline 2010 & 1.421 .860 & 34,91 \\
\hline 2011 & 1.918 .172 & 101,49 \\
\hline 2012 & 3.864 .899 & 22,86 \\
\hline 2013 & 4.748 .576 & 16,69 \\
\hline 2014 & 5.541 .327 & 33,66 \\
\hline 2015 & 7.406 .647 & 30,70 \\
\hline 2016 & 9.680 .846 & 26,16 \\
\hline 2017 & 12.213 .458 & 58,32 \\
\hline 2018 & 19.336 .841 & 34,79 \\
\hline 2019 & 26.064 .213 & Rata-rata $: 40,59$ \\
\hline TOTAL & $\mathbf{9 2 . 1 9 6 . 8 3 9}$ & \\
\hline
\end{tabular}

Sumber : PT BPRS Rahmania Dana Sejahtera, Bireuen 2020 


\section{b. Analisis Verifikatif}

\section{1). Pengujian Model Jalur-1: Pengaruh DPK dan Asset terhadap Pembiayaan}

Dalam penelitian ini model analisis pertama, yakni menganalisis pengaruh DPK $\left(\mathrm{X}_{1}\right)$ dan Asset $\left(\mathrm{X}_{2}\right)$ terhadap Pembiayaan $(Y)$. Dengan model: $Y=f(X 1, X 2)=\rho_{1} X_{1}+\rho_{1} X_{2}+\varepsilon_{1}$. Adapun pembuktian masingmasing koefisien jalur melalui hipotesis secara parsial, dapat dilihat pada tabel berikut ini:

\section{Uji Secara Parsial}

Tabel 7. Uji Signifikansi Koefisien Jalur

\begin{tabular}{|c|c|c|c|c|}
\hline \multirow[b]{2}{*}{ Model } & \multicolumn{2}{|c|}{ Standardized Coefficients } & \multirow[t]{2}{*}{$\mathrm{t}$} & \multirow[t]{2}{*}{ Sig. } \\
\hline & & Beta & & \\
\hline (Constant) & & & -.391 & .698 \\
\hline DPK & $\rho_{1}=$ & .477 & 6.150 & .000 \\
\hline Asset & $\rho_{2}=$ & .525 & 6.779 & .000 \\
\hline
\end{tabular}

Dependent variable : Pembiayaan,

Sumber : Hasil olah Spss, 20202

Berdasarkan data tabel 7. diatas, maka dilakukan uji hipotesis berikut:

\section{Hipotesis 1}

Ho: $\rho_{\mathrm{yx} 1} \leq 0$ : Dana Pihak Ketiga (DPK) tidak berpengaruh terhadap Pembiayaan

$\mathrm{H}_{1}: \rho_{\mathrm{yx} 1}>0$ : Dana Pihak Ketiga (DPK) berpengaruh terhadap Pembiayaan

Kriteria pengujian adalah total Ho jika $t_{\text {hitung }}>t_{\text {tabel }}$ dimana $t_{\text {tabel }}$ untuk $\alpha=5 \%$ adalah 1,645. Hipotesis ini menyatakan ada pengaruh DPK $\left(\mathrm{X}_{1}\right)$ terhadap Pembiayaan $(\mathrm{Y})$. Dengan koefisien jalurnya $\rho_{\mathrm{yx} 1}=0,477$. Hasil perhitungan uji individu menunjukkan harga $\mathrm{t}_{\text {hitung }}$ sebesar 6,150 , sedangkan $\mathrm{t}$-tabel dengan gtaraf uji $5 \%$ adalah $t$-tabel $=1,725$. Dengan demikian $t_{\text {hitung }}>t_{\text {tabel }}(6,150>1,725)$. Sehingga Ho ditolak dan H1 diterima, artinya koefisien jalur DPK $\left(\mathrm{X}_{1}\right)$ terhadap Pembiayaan $(\mathrm{Y})$ dapat dinyatakan signifikan pada taraf sig. $\alpha=5 \%$. Dengan demikian dapat dinyatakan bahwa adanya Dana pihak ketiga (DPK) dapat mempengaruhi Jumlah Pembiyaan pada Nasabah PT. BPRS Dana Sejahtera.

\section{Hipotesis 2}

Ho: $\rho_{\mathrm{yx} 2} \leq 0$ : Asset tidak berpengaruh terhadap Pembiayaan

$\mathrm{H}_{1}: \rho_{\mathrm{yx} 2}>0$ : Asset berpengaruh terhadap Pembiayaan

Dengan koefisien jalurnya $\rho_{\mathrm{yx} 2}=0,525$. Hasil perhitungan uji individu menunjukkan harga $\mathrm{t}_{\text {hitung }}$ sebesar 6,779. Dengan demikian $t_{\text {hitung }}>t_{\text {tabel }}(6,779>1,725)$. Sehingga Ho ditolak dan H1 diterima artinya koefisien jalur Asset $\left(\mathrm{X}_{2}\right)$ berpengaruh terhadap Pembiayaan $(\mathrm{Y})$.

\section{Uji Model Secara Simultan}

Dalam penelitian ini model analisis dengan analisis jalur yang menentukan pengaruh variabel DPK $\left(\mathrm{X}_{1}\right)$, dan Asset $\left(\mathrm{X}_{2}\right)$ terhadap Pembiayaan BPRS $(\mathrm{Y})$.

Dengan model $\mathrm{Y}=\mathrm{f}(\mathrm{X} 1 . \mathrm{X} 2)=\rho_{1} \mathrm{X}_{1}+\rho_{2} \mathrm{X}_{2}+$ e. $\quad$ Adapun pembuktian hipotesis secara simultan (keseluruhan) dapat dilihat pada tabel 8 berikut ini:

Tabel 8. Uji Model Analisis Secara Simultan

\begin{tabular}{|l|r|r|r|c|c|}
\hline Model & Sum of Squares & Df & Mean Square & F & Sig. \\
\hline Regression & 9.596 & 2 & 4.798 & 784.381 & $.000^{\mathrm{a}}$ \\
Residual & .226 & 37 & .006 & & \\
Total & 9.822 & 39 & & & \\
\hline
\end{tabular}

a. Predictors: (Constant), DPK, Asset, Dependent Variable: Pembiayaan

Berdasarkan hasil uji $\mathrm{F}$ diperoleh nilai $\mathrm{F}_{\text {hitung }}$ sebesar 784,381, sementara nilai $\mathrm{F}_{\text {tabel }}$ untuk jumlah unit data sebanyak 40 orang $(\mathrm{N}=40)$ pada tingkat signifikansi $(\alpha)=5 \%$ yaitu sebesar 3,23. Hal ini menunjukkan bahwa $F_{\text {hitung }}>F_{\text {tabel }}$ dengan tingkat signifikansi 0,05 . Hal ini juga tampak dalam kolom-6 tabel 4.7 diatas, yang menyatakan nilai signifikansinya pada 0.000 . Dengan demikian dapat disimpulkan bahwa probabilitas dalam penelitian ini lebih kecil dari $0,05 \%$ maka hipotesis nol (Ho) ditolak, yang berarti bahwa variabel DPK $\left(\mathrm{X}_{1}\right)$, dan Asset $\left(\mathrm{X}_{2}\right)$ secara bersama-sama atau simultan berpengaruh signifikan terhadap Pembiayaan BPRS (Y). 
Berdasarkan hal diatas, dan penentuan hubungan kausal angtar variabel eksoge, yakni terdapat hubungan antar variabel eksogen, dimana korelasi DPK $\left(\mathrm{X}_{1}\right)$ dan Asset $\left(\mathrm{X}_{2}\right)$ termasuk tinggi yakni : 0,947. Maka model kausal yang dibentuk secara teoritik diperoleh diagram jalur seperti gambar 3, berikut;

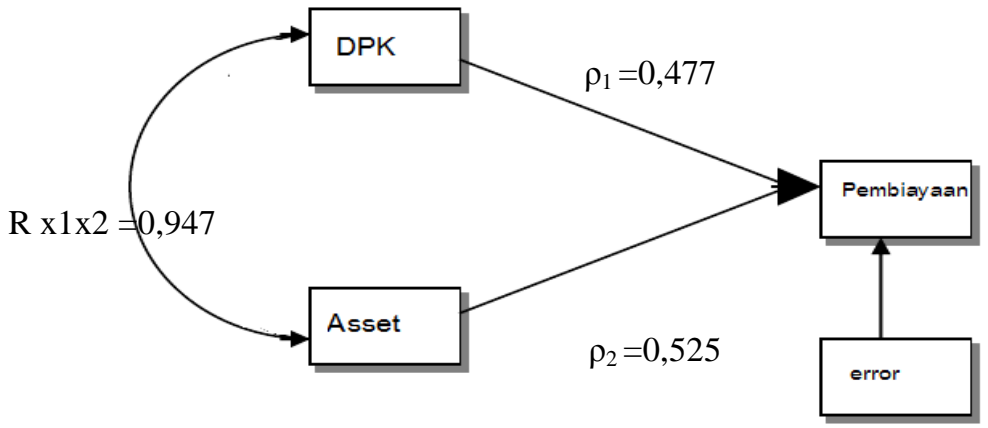

Gambar 3. Diagram Jalur Penelitian

Keterangan : $\quad r_{\mathrm{x} 1, \mathrm{x} 2}=$ Hubungan kausal antar variabel eksogen (DPK dan Asset)

$\rho_{\mathrm{i}} \quad=$ Nilai Koefisien Jalur (Path) yang menyatakan pengaruh langsung antar variabel eksogen terhadap variabel endogen.

\section{2). Analisis Pengaruh DPK dan Asset terhadap Pembiayaan}

\section{Pengaruh DPK terhadap Pembiayaan BPRS}

1. Pengaruh langsung: Dana Pihak Ketiga $\left(\mathrm{X}_{1}\right)$ terhadap Pembiayaan $(\mathrm{Y})$, dinyatakan dengan besaran koefisien jalur $\left(\rho_{\mathrm{yx} 1}=0,477\right)$, sehingga besarnya pengaruh langsung ini adalah: $22,75 \%$.

2. Pengaruh Tidak langsung, DPK $\left(\mathrm{X}_{1}\right)$ terhadap Pembiayaan $(\mathrm{Y})$, karena adanya hubungan kausal DPK dan Asset $\left(\mathrm{X}_{2}\right)$, dinyatakan dengan besaran koefisien jalur, dan koefisien korelasi dari hubungan antar variabel dimaksud, yaitu: $23,71 \%$

3. Pengaruh Total DPK $\left(X_{1}\right)$ terhadap Pembiayaan $(Y)$

Berdasarkan pengaruh langsung dan tidak langsung, maka dapat dihitung besarnya pengaruh total Dana pihak ketiga/DPK $\left(\mathrm{X}_{1}\right)$ terhadap Pembiayaan BPRS (Y), yakni : 46,46\%.

Pengaruh Asset terhadap Pembiayaan BPRS

1. Pengaruh langsung: Asset $\left(\mathrm{X}_{2}\right)$ terhadap Pembiayaan $(\mathrm{Y})$, dinyatakan dengan besaran koefisien jalur $\left(\rho_{\mathrm{yx} 2}=0,525\right)$, Sehingga besarnya pengaruh langsung ini adalah: $27,56 \%$.

2. Pengaruh Tidak langsung; Asset $\left(\mathrm{X}_{2}\right)$ terhadap Pembiayaan $(\mathrm{Y})$, karena adanya hubungan kausal DPK dan Asset $\left(\mathrm{X}_{2}\right)$, dinyatakan dengan besaran koefisien jalur, dan koefisien korelasi dari hubungan antar variabel dimaksud, yaitu: $23,71 \%$

3. Pengaruh Total Asset $\left(X_{2}\right)$ terhadap Pembiayaan $(Y)$

Berdasarkan pengaruh langsung dan tidak langsung, maka dapat dihitung besarnya pengaruh total Asset $\left(\mathrm{X}_{1}\right)$ terhadap Pembiayaan BPRS (Y), yakni : 51,27\%.

\section{3). Pengujian Model Jalur-2: Pengaruh Pembiayaan terhadap Omset}

Dalam penelitian ini model analisis kedua, yakni menganalisis pengaruh Pembiayaan (Y) terhadap Omset (Z). Dengan model: $Z=f(Y)=\rho_{3} Y+\varepsilon_{2}$. Adapun pembuktiannya dapat dilihat pada tabel berikut ini:

Tabel 9. Uji Signifikansi Koefisien Jalur

\begin{tabular}{|c|c|c|c|c|c|}
\hline \multirow[b]{2}{*}{ Model } & \multicolumn{2}{|c|}{ Unstandardized Coefficients } & \multirow{2}{*}{$\begin{array}{c}\text { Standardized Coefficients } \\
\text { Beta } \\
\end{array}$} & \multirow[b]{2}{*}{$\mathrm{T}$} & \multirow[b]{2}{*}{ Sig. } \\
\hline & $\mathrm{B}$ & Std. Error & & & \\
\hline (Constant) & 4.163 & .097 & & 42.844 & .000 \\
\hline & .634 & .015 & .990 & & .000 \\
\hline
\end{tabular}

a. Dependent Variable: Omset, Sumber : Hasil olah spss

Dari tabel 9 diatas, maka koefsien jalur Y terhadp Z sebesar $\rho_{3}=0,99$. Yang digambarkan sebagai berikut:

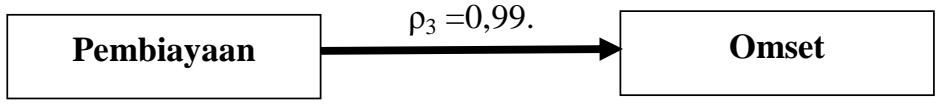

Gambar 4 Diagram Jalur Penelitian 
Dari ukuran dalam gambar 4 diatas, maka besarnya pengaruh Pembiayaan (Y) terhadap Omset (Z) adalah 98 persen.

\section{4). Pengaruh DPK dan Asset terhadap Omset melalui Pembiayaan BPRS}

Adapun tujuan akhir dalam penelitian adalah menentukan secara kalkulasi, seberapa besar pengaruh Dana pihak ketiga (DPK), dan Asset PT. BPRS Rahmania Dana Sejahtera, terhadap Omset, melalui kegiatan pembiayaan pada Nasabah. Untuk itu digambarkan berikut ini :

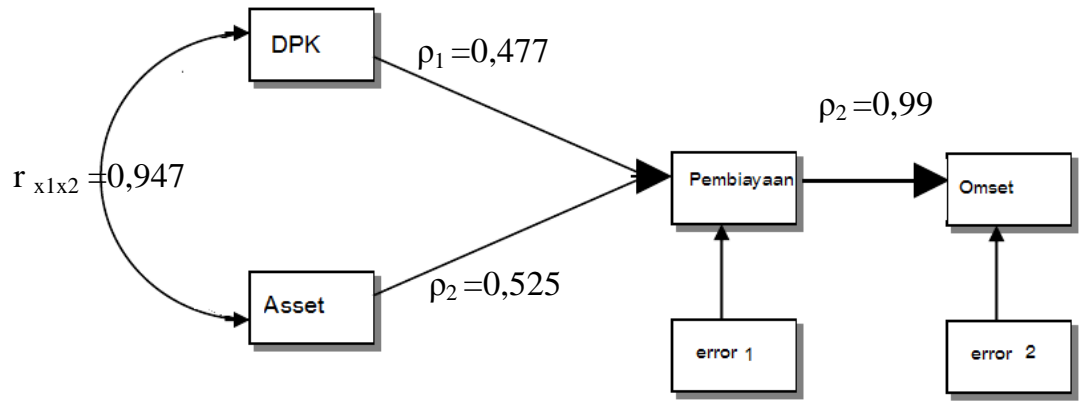

Gambar 5. Diagram Jalur Penelitian tentang DPK, Asset terhadap Omset melalui Pembiayaan

\section{c. Pembahasan}

Berdasarkan hasil pengolahan data tentang keterkaitan antar variabel Dana Pihak Ketiga, Asset PT. BPRS Rahmania Dana Sejahtera, terhadap Omzet UMKM melalui Pembiayaan UMKM pada PT. BPRS Rahmania Dana Sejahtera, maka berikut dilakukan pembahasannya baik dari substanial dan empiris data yang diamati selama tahun 2010 sampai 2019.

\section{1). Pengaruh Dana Pihak Ketiga (DPK) dan Asset terhadap Pembiayaan UMKM}

DPK merupakan faktor penting bagi pembiayaan UMKM yang dijalankan BPRS. Hal ini adalah paling berpengaruh karena dana pihak ketiga dapat dikendalikan oleh BPRS yang merupakan sisi pendanaan, dimana dana yang semakin meningkat harus diimbangi dengan penyaluran pembiayaan yang dapat menggerakan sektor riil. Semakin meningkatnya DPK yang dikumpulkan BPRS maka kemungkinan semakin meningkat pula pembiayaan atau penyaluran dana yang diberikan kepada masyarakat. Kemampuan BPRS dalam menghimpun dana berarti BPRS tersebut memiliki kredibilitas yang tinggi dari masyarakat.

Demikian juga asset BPRS dalam menjamin kelancaran pembiayaan UMKM. Struktur asset perusahaan memainkan peranan penting dalam menentukan pembiayaan perusahaan yang memiliki aktiva tetap jangka panjang, karena permintaan akan produk mereka tinggi, akan banyak menggunakan utang hipotik jangka panjang. Perusahaan yang sebagian aktivanya berupa piutang dan persediaan barangnya yang nilainya sangat tergantung pada kelanggengan tingkat profitabilitas tidak terlalu tergantung pada pembiayaan jangka pendek.

Hasil penelitian menunjukkan bahwa, terdapat pengaruh langsung dan tidak langsung, Dana Pihak Ketiga (DPK) terhadap Pembiayaan UMKM oleh BPRS sebesar 46,46 persen. Demikian pula terdapat pengaruh yang signifikans Total Asset terhadap Pembiayaan BPRS, yakni sebesar 51,27 persen. Kontribusi keduanya (baik DPK dan Asset) pada BPRS terhadap perubahan yang terjadi pada pembiayaan UMKM sebesar 97,7\%.

Penelitian Vivi Desey Wulandari (2019) tentang pengaruh Dana Pihak Ketiga (DPK), Return On Asset (ROA), Dan Non Perfoming Financing (NPF) Terhadap Penyaluran Pembiayaan Syariah Kepada UMKM oleh BPRS di Kabupaten Banyumas, menyatakan: "Bagi Nasabah dan Investor apabila ingin melakukan pembiayaan dan menginvestasikan dananya di BPRS tidak harus melihat berapa besar besar tingkat ROA dan NPF yang diperoleh oleh BPRS, karena ROA dan NPF tidak memberikan pengaruh terhadap penyaluran pembiayaan syariah kepada UMKM. Sedangkan bagi nasabah dan investor apabila ingin melakukan pembiayaan dan menginvestasikan dananya di BPRS harus melihat berapa besar DPK yang diperoleh BPRS, karena DPK memberikan pengaruh terhadap penyaluran pembiayaan syariah kepada UMKM".

Penelitian yang dilakukan oleh Oki Irawan, Jafril Khalil dan A. Riawan Amin (2016) yang berjudul: "Dana Pihak Ketiga, Rasio Kecukupan Modal, Pembiayaan Bermasalah, dan Tingkat Pengembalian Investasi pada Pembiayaan UMKM". Dana Pihak Ketiga memiliki pengaruh sangat kuat dan terarah terhadap alokasi pembiayaan UMKM pada perbankan syariah. Dengan dugaan bahwa variabel jumlah dana pihak ketiga merupakan variabel yang paling berkaitan dengan alokasi pembiayaan UMKM. Selain itu, penelitian yang dilakukan oleh Purwidianti dan Hidayah (2014) tentang "Faktor-Faktor yang Mempengaruhi Alokasi 
Pembiayaan Perbankan Syariah untuk Usaha Mikro Kecil dan Menengah di Indonesia”. Menyatakan bahwa dana pihak ketiga memiliki pengaruh positif signifikan terhadap pembiayaan perbankan syariah untuk UMKM. Peningkatan dana pihak ketiga akan mengakibatkan peningkatan jumlah pembiayaan yang mampu disalurkan oleh perbankan syariah.

Penelitian yang dilakukan oleh Astuti (2013) dan Suharjo (2010) juga menyebutkan bahwa DPK ikut berpengaruh signifikan terhadap pembiayaan UKM. Hal ini menunjukkan bahwa dana masyarakat memang berperan penting terhadap kemampuan bank menyalurkan kreditnya dalam rangka membantu kebutuhan atau usaha masyarakat. Penelitian Ratnasari dan Soesatyo (2015) juga mendukung bahwa dana pihak ketiga berpengaruh terhadap penyaluran kredit UMKM. Dana pihak ketiga merupakan sumber dana masyarakat yang dihimpun bank yang terdiri dari giro, tabungan dan deposito. Dana pihak ketiga merupakan input dalam menyalurkan kredit. Semakin banyak dana pihak ketiga yang dihimpun, semakin mudah bank dalam menyalurkan kredit kepada pihak yangmembutuhkan. Hal yang menyebabkan DPK berpengaruh signifikan adalah adanya kesesuaian data mengenai kenaikan nilai DPK dan nilai penyaluran kredit. Tingginya DPK dikarenakan beberapa faktor diantaranya perbankan di Indonesia dan pemerintah dianggap lebih solid dalam menghadapi krisis.

\section{2). Pengaruh Pembiayaan UMKM terhadap Omset}

Hasil penelitian yang dilakukan pada PT. BPRS Rahmania Dana Sejahtera, terdapat pengaruh Pembiayaan terhadap Omset secara signifikans, yakni sebesar 98 persen. Hasil ini di dukung oleh penelitian Singgih Muheramtohadi (2017) yang meneliti tentang Peran Lembaga Keuangan Syariah Terhadap Pemberdayaan UMKM Indonesia menyatakan bahwa LKS memberikan pembiayaan yang diperuntukkan pada pelaku UMKM mempunyai pengaruh yang positif. Menurut Ananda Fitra (2011) meneliti tentang Analisis Perkembangan Usaha Mikro dan Kecil Setelah Memperoleh Pembiayaan Mudharabah dari BMT AT Taqwa Halmahera di Kota Semarang menyatakan bahwa pembiayaan berpengaruh terhadap modal usaha, omset penjualan dan keuntungan BMT AT Taqwa Halmahera.

\section{3). Pengaruh DPK dan Asset terhadap Omset melalui Pembiayaan UMKM}

Dalam penelitian Siti Jubaedah dan Rina (2015) yang meneliti tentang implikasi pembiayaan syariah terhadap usaha mikro kecil dan menengah (UMKM) di Kabupaten Cirebon. Penelitian ini menghasilkan bahwasannya pembiayaan syariah dengan Akad mudharabah (Trustee Profit Sharing) dan musyarakah berpengaruh positif signifikan terhadap perkembangan asset UMKM di Kabupaten Cirebon. Pembiayaan syariah Akad mudharabah (Trustee Profit Sharing) dan musyarakah berpengaruh positif signifikan terhadap perkembangan omset penjualan UMKM di Kabupaten Cirebon. Hasil dari penelitian tersebut menunjukkan bahwa terdapat peningkatan penjualan pada UMKM. Peningkatan itu terjadi karena UMKM dapat menjaga harga jual supaya tidak mengalami penurunan, serta terdapat pelanggan dan perputaran modal yang baik. Sehingga pembiayaan Syariah yang disalurkan untuk UMKM dapat dibuktikan melalui peningkatan penjualan

Berdasarkan hasil penelitian Saiful Muaiz (2017) tentang pengaruh Pembiayaan Murabahah terhadap omset penjualan dan keuntungan nasabah UKM di Baitul Maal Wat Tamwil Al Ishlah Bobos Cerebon bahwa besar kecilnya nilai pembiayaan murabahah dan nilai omset penjualan dapat dilihat dari determinan, sebesar $71,06 \%$. Artinya, bahwa nilai pembiayaan murabahah berpengaruh secara positif terhadap nilai omset penjualan Usaha Kecil dan Menengah (UKM) di Baitul Maal Wat Tamwil Al-Ishlah Bobos Kecamatan Dukupuntang Kabupaten Cirebon dengan kisaran hubungan sebesar 71,06\%.

Dari beberapa penelitian yang sudah dilakukan sebelumnya membuktikan bahwa pembiayaan yang di berikan oleh lembaga keuangan syariah dapat meningkatkan omset UMKM. Dalam penelitian ini juga menunjukkan bahwa, terdapat pengaruh langsung dan tidak langsung, Dana pihak ketiga (DPK) terhadap Pembiayaan UMKM oleh sebesar 46,46 persen dan terdapat pengaruh yang signifikans Total Asset terhadap Pembiayaan UMKM sebesar 51,27 persen. Dimana kontribusi keduanya (DPK dan Asset) terdapat pengaruh yang cukup signifikans terhadap pembiayaan UMKM sebesar 97,7 persen.

\section{Simpulan dan Saran (Conclusions and Suggestions)}

\section{a. Simpulan (Conclusion)}

Berdasarkan hasil dan pembahasan masalah penelitian ini, dapat ditarik beberapa simpulan dan temuan, sebagai berikut:

1. Perkembangan Omset UMKM sebagai nasabah BPRS selama 10 tahun terakhir yakni 2010-2019 menunjukkan hal yang meningkat, dengan rata-rata setiap tahun sebesar Rp.175.900.000 dan peningkatannya rata-rata $25,09 \%$ per tahun. 
2. Pembiayaan UMKM yang disalurkan BPRS, dengan prinsip akad murabahah, mudharabah dan musyarakah pada setiap tahun juga menunjukkan peningkatan, dengan rata-rata pertumbuhan tahunannya sebesar $45,79 \%$.

3. Penghimpunan Dana Pihak Ketiga (DPK) pada BPRS, juga menunjukkan perkembangan. Dari awalnya 2010 sejumlah Rp. 174.749.000, meningkatkan tajam pada tahun 2019 menjadi Rp.15.877.550.000.

4. Asset perbankan syariah meliputi kas, penempatan dana pada BI, penempatan pada bank lain, pembiayaan yang diberikan, penyertaan, Penyisihan Penghapusan Akitva Produktif, Aktiva Tetap, serta Rupa-Rupa Aktiva. Perkembangan jumlah asset di BPRS, selama 10 tahun terakhir sangat baik dari tahun ke tahun. Kenaikan rata-rata per tahun mencapai 40,59\%.

5. Hasil analisis data pada PT. BPRS Rahmania Dana Sejahtera, selama 10 tahun terakhir (2010-2019), menunjukkan bahwa:

a. Terdapat pengaruh positif total dana pihak ketiga terhadap pembiayaan UMKM, yakni 46,46\%

b. Terdapat pengaruh positif dan signifikans antara asset terhadap Pembiayaan UMKM sebesar $51,27 \%$

c. Terdapat pengaruh positif dan signifikans antara dana pihak ketiga, asset terhadap pembiayaan UMKM, yakni sebesar $97,7 \%$.

d. Terdapat pengaruh positif dan signifikans antara pembiayaan UMKM terhadap Omset UMKM, adalah sebesar $98 \%$

e. Terdapat pengaruh positif dan signifikans dana pihak ketiga terhadap asset, adalah sebesar $94 \%$.

\section{b. Saran (Suggestions)}

BPRS terus menjaga kepercayaan masyarakat dan stakeholder, dengan cara meningkatkan pembiayaan sektor usaha UMKM sehingga Omset UMKM akan semakin meningkat dan secara pengembalian pembiayaan yang diberikan akan lancar dan akan mempengaruhi peningkatan pendapatan BPRS. Dengan demikian semakin banyaknya pendapatan yang diperoleh maka semakin banyak bagi hasil yang dibagikan kepada pihak yang memiliki dana hal ini akan meningkatakan kepercayaan masyarakat dan stakeholder untuk menempatkan dana di BPRS semakin tinggi.

BPRS perlu menerapkan prinsip kehati-hatian dalam proses penyaluran pembiayaan untuk meminimalkan potensi meningkatnya permbiayaan bermasalah yang akan mengakibatkan macetnya pengembalian pembiayaan sehingga laba BPRS dan bagi hasil yang di bagikan kepada pihak katiga sedikit sehingga muncul ketidak percayaan masyarakat kepada perusahaan yang akhirnya akan menarik dananya, yaitu :

1) Melakukan analisis secara komprehensif terhadap aspek 5C+1S yaitu Character, Capacity, Capital, Condition, Collateral dan Syariah pada nasabah

2) Memastikan pengikatan agunan sudah sesuai detentuan

3) Memastikan pembiayaan yang diberikan sesuai dengan karakteristik usaha dan jumlah sesuai dengan kemampuan

4) Melakukan monitoring (pemantauan) pasca realisasi pembiayaan untuk memastikan tujuan penggunaan pembiayaan tidak menyimpang dan sesuai dengan akad.

\section{DAFTAR PUSTAKA (References)}

1) Achmad Rifa'i. Peran Bank Pembiayaan Rakyat Syariah Dalam Mengimplementasikan Keuangan Inklusif Melalui Pembiayaan UMKM. Awardee LPDP PK-70, Program Magister Sains Ilmu Ekonomi Fakultas Ekonomika Dan Bisnis, Universitas Gadjah Mada. Human Falah: Volume 4. No. 2 Juli - Desember 2017.

2) Ainun Asifah dan A'rasy Fahrullah Pengaruh Pembiayaan Murabahah Terhadap Perkembangan UMKM Di Kecamatan Ngoro. Jurnal Ekonomi Islam. Vol 2 No 3 Tahun 2019

3) Ali, Mahbubi M dan Ascarya. 'Analisis Efisiensi Baitul Maal Wat Tamwil dengan pendekatan Two Stage Data Envelopment Analysis'. TAZKIA Journal of Islamic Finance and Business Review, Vol.5, No.2, pp. 110-125. Tahun 2010.

4) Ananda, F. (2011). Analisis Perkembangan Usaha Mikro dan Kecil Setelah Memperoleh Pembiayaan Mudharabah dari BMT AT Taqwa Halmahera di Kota Semarang. Hasil Penelitian

5) Ati Astuti, (2013), Pengaruh Inflasi, Bi Rate, Dana Pihak Ketiga (DPK), Non Performing Loan (NPL) dan Capital Adequacy Ratio (CAR) terhadap Penyaluran Kredit (Studi Kasus Pada Bank Terbesar Di Indonesia Berdasarkan Kredit), Jakarta : Hasil Penelitian

6) Badan Pusat Statistik Kabupaten Bireuen, 2018. "Statistik Kabupaten Bireuen 2018" http://bireuenkab.bps.go.id.

7) Ghozali, Imam. 2005. Aplikasi Analisis Multivariate dengan SPSS. Semarang: Badan Penerbit UNDIP.

8) https://www.ojk.go.id/id/kanal/syariah/tentang-syariah/Pages/PBS-dan-Kelembagaan.aspx 
9) Irawan, Oki., Khalil, Jafril., dan A. Riawan Amin. (2016). Dana Pihak Ketiga, Rasio Kecukupan Modal, Pembiayaan Bermasalah, dan Tingkat Pengembalian Investasi pada Pembiayaan UMKM. Jurnal Liquidity, Vol. 5, No. 2

10) Ismail. (2011). Manajemen Perbankan: Dari Teori Menuju Aplikasi. Jakarta: Kencana.

11) Jianti, Listya Gita. 2015. "Efisiensi Bank Umum Syariah dan Bank Pembiayaan Rakyat Syariah". Skripsi Fakultas Ekonomi Universitas Negeri Semarang.

12) Kara, M. 2013. Kontribusi Pembiayaan Perbankan Syariah Terhadap Pengembangan Usaha Mikro Kecil Dan Menengah (UMKM) di Kota Makasar. Ekonomi Islam, 47(1).

13) Marcellina, A. L. (2012). Analisis Dampak Kredit Mikro Terhadap Perkembangan Usaha Mikro di Kota Semarang. diakses dari http://eprints.undip.ac.id/35985/1/ MARCELLINA.pd

14) Maryati, Sri. Peran Bank Pembiayaan Rakyat Syariah dalam Pengembangan UMKM dan Agribisnis Pedesaan di Sumatera Barat, Vol.3 No. 1 Maret 2014, hlm. 2-3.

15) Nining Sudiyarti, Ismawati \& Agus Irwansyah. Pengaruh Usaha Mikro Kecil Menengah (UMKM) Terhadap Pertumbuhan Ekonomi Daerah Kabupaten Sumbawa Tahun 2011-2015. Fakultas Ekonomi \& Manajemen Universitas Samawa Program Studi Ekonomi Pembangunan ISSN (P) : 2089-1210, E-ISSN : 2580-7285 Jurnal Ekonomi dan Bisnis Vol 14 No 2, Agustus 2017.

16) Otoritas Jasa Keuangan 2014. "Peraturan Otoritas Jasa Keuangan yang terdapat pada Peraturan Otoritas Jasa Keuangan Nomor 21/POJK.03/2014 mengenai Kewajiban Penyediaan Modal Minimum Bank Umum Syariah. https://www.ojk.go.id/id/kanal/syariah/tentang-syariah/Pages/PBS-dan-Kelembagaan.aspx

17) Otoritas Jasa Keuangan 2014. "Surat Edaran Otoritas Jasa Keuangan Nomor 10/SEOJK.03/2014 mengenai Penilaian Tingkat Kesehatan Bank Umum Syariah dan Unit Usaha Syariah”.

18) Otoritas Jasa Keuangan 2014. "Surat Edaran Otoritas Jasa Keuangan Nomor 16/POJK.03/2014 mengenai Penilaian Kualitas Aset Bank Umum Syariah dan Unit Usaha Syariah".

19) Otoritas Jasa Keuangan 2016. "Peraturan Otoritas Jasa Keuangan Nomor 6/POJK.03/2016 mengenai Kegiatan Usaha dan Jaringan Kantor Berdasarkan Modal Inti Bank, Bank Umum berdasarkan Kegiatan Usaha”. https://www.ojk.go.id/id/kanal/syariah/tentang-syariah/Pages/PBS-dan-Kelembagaan.aspx

20) Otoritas Jasa Keuangan. 2015. "Statistik Perbankan Syariah Juni 2015". https://www.ojk.go.id/id/kanal/syariah/tentang-syariah/Pages/PBS-dan-Kelembagaan.aspx

21) Otoritas Jasa Keuangan. 2016. "Statistik Perbankan Syariah Otoritas Jasa Keuangan”, 14(7), 1-103. https://www.ojk.go.id/id/kanal/syariah/tentang-syariah/Pages/PBS-dan-Kelembagaan.aspx

22) Purwidianti, Wida., dan Arini Hidayah. (2014). Faktor-faktor yang Mempengaruhi Alokasi Pembiayaan Perbankan Syariah untuk Usaha Mikro kecil dan Menengah di Indonesia. Prosiding Seminar Hasil Penelitian LPPM UMP, ISBN 978-602-14930-2-1.Purwokerto.

23) Sugiyono, 2014. Metode Penelitian Manajemen. Bandung: Alfabeta.

24) Suharjo, (2010), Analisis Pengaruh ROA, CAR, NPL, DPK, Suku Bunga SBI, Dan InflasiTerhadap Pertumbuhan UMKM Pada Bank Umum Di Indonesia Periode 2004-2010,( JurnalTidak Diterbitkan)

25) Suprihatmi Sri Wardiningsih \& Retno Susanti, Pengaruh Modal Kerja, Aset, Dan Omzet Penjualan Terhadap Laba UKM Catering Di Wilayah Surakarta. Fakultas Ekonomi Universitas Slamet Riyadi Surakarta, Fakultas Ekonomi Universitas Slamet Riyadi Surakarta. Jurnal Perilaku Dan Strategi Bisnis Vol.5 No.1, 2017 Hal. 84 - 93.

26) Syaiful Muaiz. Pengaruh Pembiayaan Murabahah Terhadap Omset Penjualan Dan Keuntungan Nasabah Usaha Kecil Dan Menengah (UKM) Di Baitul Maal Wat Tamwil Al-Ishlah Bobos Cirebon. Inklusif, Vol 2. No 1 Juni 2017.

27) Undang-undang Republik Indonesia No. 20 tahun 2008 tentang Usaha Mikro, Kecil, dan Menengah.

28) Undang-undang Republik Indonesia No. 21 tahun 2008 Tentang Perbankan Syariah.

29) Undang-undang Republik Indonesia Nomor 9 Tahun 1995 Tentang Usaha Kecil dan Menengah.

30) Vivi Desey Wulandari (2019) tentang pengaruh Dana Pihak Ketiga (DPK), Return On Asset (ROA), Dan Non Perfoming Financing (NPF) Terhadap Penyaluran Pembiayaan Syariah Kepada UMKM oleh BPRS di Kabupaten Banyumas, Hasil Penelitian. 